\title{
On pilgrimage with biblical women in their land(s)
}

\author{
Author: \\ Elaine M. Wainwright ${ }^{1,2}$ \\ Affiliations: \\ ${ }^{1}$ School of Theology, \\ University of Auckland, \\ New Zealand \\ ${ }^{2}$ Department of New \\ Testament Studies, \\ University of Pretoria, \\ South Africa \\ Note: \\ Prof. Dr Elaine M. \\ Wainwright participates \\ in the research project \\ 'Biblical Theology and \\ Hermeneutics', directed \\ by Prof. Dr Andries G. van \\ Aarde, Honorary Professor \\ of the Faculty of Theology \\ at the University of \\ Pretoria, South Africa. \\ Correspondence to: \\ Elaine Wainwright \\ email: \\ em.wainwright@auckland. \\ ac.nz
}

Postal address:

School of Theology,

University of Auckland,

Private Bag 92019,

Auckland, New Zealand

Dates:

Received: 31 Aug. 2010

Accepted: 09 Oct. 2010

Published: 07 June 2011

How to cite this article:

Wainwright, E.M., 2011

'On pilgrimage with biblical

women in their land(s)',

HTS Teologiese Studies/

Theological Studies 67(1),

Art. \#918, 7 pages. DOI:

10.4102/hts.v67i1.918

(C) 2011. The Authors. Licensee: OpenJournals Publishing. This work is licensed under the Creative Commons Attribution License.
Recent sociological and anthropological studies have provided models for examining pilgrimage both in its ancient and contemporary manifestations. Such models can facilitate an examination of the phenomenon of study tours to biblical lands and the multivalence of the discourses associated with such tours. The first part of the article engaged critically with the literature in order to open up some frameworks for examining the study tour to biblical lands. Feminist critical biblical scholarship with its potential for a feminist hermeneutic of creative imagination contributes to the multivalence around the study tour. Therefore, the second part of the article engaged this scholarship in relation to an imagined tour with women of the biblical lands. The article highlighted significant issues for consideration for those planning a study tour of biblical lands, especially in terms of the consideration that ought to be paid to gender.

\section{Introduction}

Currently anthropologists, sociologists and ethnographers are exploring the distinctions and/or intersections between pilgrimage and tourism or religious tourism. These categories, however, do not readily include the accompanying and leading of students and pilgrims on study tours of the 'biblical lands', ${ }^{1}$ a task I have undertaken on several occasions over the past decade and a half. The impetus for such study tours was my experience of exploring these lands during my time at the École Biblique et Archaeologique Française during the academic years 1984-1986. There, the excursions into 'biblical lands' involved careful preparation by both students and the director and they belonged within a planned academic programme as did the study tours I subsequently conducted.

During the years of my study in Jerusalem in the 1980s and my leading of study tours to biblical lands in the 1990s, the scholarly lens had not been directed so explicitly to the exploration of pilgrimage and religious tourism as it is at present. Neither had these categories been considered within feminist biblical scholarship in which I was engaged. This article is positioned within critical feminist biblical scholarship. It brings this scholarship into dialogue with the emerging literature on pilgrimage and tourism and its lack of explicit attention to study tours and critically assesses its potential for dialogue with feminist biblical studies and women's spirituality. In the second part of the article, I explicitly employ a 'hermeneutics of creative imagination'. ${ }^{2}$ I will dialogue, where appropriate, with a range of the feminist biblical scholarship that has characterised the past three decades whilst exploring the potential open to women to make pilgrimage with the women of the biblical narrative in the lands associated with their stories. ${ }^{3}$ This study will be conducted by way of dialogue with the relevant literature and my own memories of experiences associated with certain sites that have particular links to women of the biblical story and also to the Divine One of that story imaged female. As such, it will be limited, especially in not being able to draw on the experience of the many women who have made pilgrimage together with the women of the biblical lands. My hope is that this article will invite others into studies that will address these lacunae. ${ }^{4}$ It is both privilege and pleasure to be able to offer this article in honour of our colleague, Professor Andries van Aarde. He has both supported the work of feminist biblical scholars as well as taking account of gender in some of his own writing. It is also, however, in the field of Matthean studies that both our scholarly interests and our professional associations

1.This term can encompass Israel, Egypt, Jordan, Syria, Turkey and Greece to name but some of the lands evoked in the biblical literature as context for the biblical narratives and traditions. It is in this way that I use the term throughout this essay.

2.The area of critical feminist biblical interpretation is a complex one which cannot be explored in any detail in this article. For one extensive exposition, however, see Elizabeth Schüssler Fiorenza, Wisdom Ways: Introducing Feminist Biblical Interpretation (2001) and pp. 179-183 for explicit attention to a 'hermeneutics of creative imagination'. Schüssler Fiorenza began her exploration of this aspect of a critical feminist hermeneutic for liberation in Bread not Stone: The Challenge of Feminist Biblical Interpretation (1984), pp. 20-22.

3.The 'women of the biblical narrative' will be considered as characters within a narrative and no extensive discussion will be entered into in relation to their historicity. However, both historical and narrative issues may characterise the scholarship that will have informed many of those who go on study tours. Within the biblical narrative, women are often identified with particular sites that can be associated with places specifically located today in the lands of the biblical narrative. It is at these sites that the women's stories can be remembered by the pilgrim or tourist or scholar.

4. Henry R. Carse 'Creative Ambiguities in Pilgrimage Process', (2003) includes in his thesis two appendices of the written reflections and memories of pilgrims to Jerusalem and the biblical lands. I am indebted to both Carse for his making his thesis available to me and to Kathryn Rountree who shared with me both in conversation and in print aspects of her research on women's experiences of pilgrimage to the Goddess sites of Malta and Greece. 
have intersected. I am privileged to have this article included in this volume.

\section{Study tour in the context of pilgrimage and tourism}

Pilgrimage has long characterised the biblical tradition with the Psalms of Ascent (Ps 120-134) providing the prayers that would accompany Jewish pilgrims as they made their way up to Jerusalem each year. ${ }^{5}$ Luke $2: 41-51$ witnesses to this yearly pilgrimage in its opening words: 'Now every year his [Jesus'] parents went to Jerusalem for the festival of the Passover'. Jesus himself makes this pilgrimage with his discipleship group and it is on one such occasion that he meets his death at the hands of the Roman imperial power. Not many decades later, Romans destroyed the central site of his own Jewish pilgrimage, the city of Jerusalem.

Within both the Jewish and early emerging Christian traditions, both the political and the religious impact of this destruction must have been enormous. Attention seems to have turned, therefore, during the late 1st, the 2 nd and into the 3rd century, to the development of the biblical tradition and the compilation of new written texts. Hence, even though the first identified Christian pilgrim to the lands of the Bible, Melito of Sardis, visits prior to $190 \mathrm{CE}^{6}{ }^{6}$ it is the 4 th century $\mathrm{CE}$ that is characterised with the rise of Christian pilgrimage and it is the words of a woman, Egeria, which provide us with significant insight into the experience of such pilgrimage in relation to the Bible.?

Egeria's pilgrimage seems to be impelled by a desire to 'see all the places where the children of Israel had been' $(7.1)^{8}$ and as a result she says just a little further on in her account that 'all the way I kept asking to see the different places mentioned in the Bible, and they were all pointed out to me by the holy men, the clergy and monks with us' (7.2). ${ }^{9}$ This reciprocal mapping of text onto topography and topography onto text is ritualised for Egeria: 'whenever we arrived, I always wanted the Bible passage to be read to us' (4.4). ${ }^{10}$ It was the

5.For a brief study of Jewish pilgrimage with its roots in the biblical tradition, see Simon Coleman and John Elsner, Pilgrimage Past and Present: Sacred Travel and Sacred Space in the World Religions (1995), pp. 34-47.

6.E.D. Hunt, Holy Land Pilgrimage in the Later Roman Empire AD 312-460 (1982), p. 83. Of the impetus which was to drive not only Melito but many others after him to the biblical lands, Hunt says, 'whether it was the solid literalism of those who expected to see every line of the Scriptures brought to reality before their eyes, or the sober and learned interest of a biblical scholar such as Origen, it was always the Bible which inspired their enterprise, and indeed shaped their whole conception of the Holy Land'.

7.John Wilkinson, Egeria's Travels to the Holy Land, revised edition (1981), provides readers with not only an English translation of the surviving text of Egeria's pilgrimage in the lands of the Bible but commentary, which assists in the situating of the age in
text.

8.Wilkinson, Egeria's Travels, p. 100. Here she adds 'from Rameses to the Red Sea' but her phraseology characterises other parts of her account such as 5.8 (p. 97) where she notes: 'So we were shown everything which the Books of Moses tell us took place in that valley beneath holy Sinai'.

9.Wilkinson, Egeria's Travels, p. 101.

10.Wilkinson, Egeria's Travels, p. 95. See also E.D. Hunt, 'The Itinerary of Egeria: Reliving the Bible in Fourth-century Palestine', in The Holy Land, Holy Lands, and Christian History, ed. R.N. Swanson (2000), p. 41, who describes the 'particular reciprocity of text and topography, of scriptural and physical locus' in this way: '.. everything that Egeria had been shown in contemporary Sinai, and for the rest of her Holy Land travels, was to be found in the biblical text, which itself was mapped her Holy Land travels, was to be foun
out in what she saw around her'. images of the context, of the places which she linked to the biblical narrative that she describes for her 'loving sisters' that 'it may help you ... better to picture what happened in these places when you read the holy Books of Moses' (5.8). ${ }^{11}$ Davies characterises the stream of Christian pilgrimage to the lands of the Bible that Egeria represents as 'visiting the holy places in order to understand the Bible more fully'. He goes on to say that 'this is a constant theme throughout the entire history of Christian pilgrimage ${ }^{\prime}{ }^{12}$

Egeria's account of her pilgrimage is, however, a far cry from the current studies that seek to distinguish pilgrimage from tourism or religious tourism and my own question whether the 'study tour' fits in one or other of these categories, or whether it is situated somewhere between them. Whilst there is a growing body of literature, especially in the field of anthropology, that is addressing these questions and issues, it is not within the scope of this article to enter this debate but simply to acknowledge the trends.

The parameters of the field of discourse in relation to pilgrimage have been mapped out by what might be perceived as dichotomous positions. Michael Prior recognises that under the influence of Durkheim 'pilgrimage has been regarded as a mode of reinforcing collective values which reflect the structures of society'. ${ }^{13}$ The Turners, on the other hand, developed the categories of liminality and communitas to demonstrate the anti-hierarchical nature of the pilgrimage process. ${ }^{14}$ It is in considering modern pilgrimage as a choice, like that made by the tourist, to move from the familiarity of one's own place into the liminal context either of the religious or the personal quest that the blurring of the lines between these types of activities occurs. In today's world, many of the activities, which characterise the tourist and the pilgrim en route to and on arrival in the 'other' place, lack clear definition. Therefore, within anthropological studies at least, there has emerged this conflation of pilgrimage and tourism or the more recently coined term, 'religious tourism'.

William Swatos and Luigi Tomasi bring together a number of studies that trace the journey from religious pilgrimage to the tourism, including religious tourism, which has characterised the 20th century into the 21st century. ${ }^{15}$ Tomasi (2002) concludes the opening article in the collection with the following claim:

The distinction between pilgrimage driven by faith and tourism for cultural and recreational purposes no longer holds, because contemporary pilgrimages involve such huge numbers of people

11.Wilkinson, Egeria's Travels, p. 98.

12.J.G. Davies, Pilgrimage Yesterday and Today: Why? Where? How? (1988), p. 206. Today's study tours likewise seek to understand the Bible more fully but with more complexity in the approaches available to those who participate in them: historical and social scientific approaches as well as narrative, rhetorical and a combination of a variety of methodologies.

13. Michael Prior, 'Pilgrimage to the Holy Land, Yesterday and Today', in Christians in the Holy Land, ed. Michael Prior and William Taylor (1994), p. 172; and John Eade and Michael J. Sallnow (1991), pp. 4-5, for a discussion of these positions.

14.See John Eade and Michael J. Sallnow, 'Introduction', in Contesting the Sacred: The Anthropology of Christian Pilgrimage, ed. John Eade and Michael J. Sallnow (1991) pp. 4-5, for a discussion of these positions.

15.Swatos W.H. \& Tomasi, L. (eds.), 2002, From Medieval Pilgrimage to Religious Tourism: The Social and Cultural Economics of Piety, Praeger, Westport. 
that they can only be organized in the same manner as mass tourism. Large numbers of pilgrims pass through travel agencies, accommodation facilities, catering services, and commercial businesses; they are, that is to say, part of the tourist industry. ${ }^{16}$

(Tomasi 2002:21)

In seeking to determine what distinguishes the modern pilgrim from the tourist, Tomasi speculates that it is the 'inner disposition', the 'typically human desire to seek out the sacred' ${ }^{17}$ According to Tomasi, what is clear in the literature, however, is that the notion or understanding of the 'sacred' has become 'multivalenced among the many visitors'.$^{18}$ In a similar vein, Eade and Sallnow suggest that pilgrimage needs to be conceived not in the dichotomous paradigms shaped by Durkheim and the Turners and their followers but rather as a 'realm of competing discourses' or 'varied discourses with their multiple meanings and understanding, brought to the shrine by different categories of pilgrims, by residents, and by religious specialists'. ${ }^{19}$ Within such a context, there is also space for a gendering of such discourses and an analysis of such gendering.

It is here, also, that a space is made for a consideration of the study tour undertaken by students and teachers of biblical studies in theological colleges and universities. Davies has indicated that 'visiting the holy places in order to understand the Bible more fully' has been 'a constant theme throughout the entire history of Christian pilgrimage' ${ }^{20}$ It is to understand the Bible more fully that these 'religious specialists' undertake their journey to the lands of the Bible. They will often read and hear the biblical text in places that have been associated with particular sections of the text just as Egeria did. They use modern photographic technology so that they can 'better to picture what happened in these places' not only when they read the biblical text back in their own place but also when they enable others 'better to picture what happened' ${ }^{21}$ They indeed come as pilgrims to encounter the divine in the places that the biblical story associates with God, with Jesus and with all of those who are part of that sacred story.

Participants in study tours also come, however, with their site maps developed from the work of archaeologists over the past century or more and with the knowledge with which this science has furnished them. They come too with both the language and the understandings of contemporary biblical scholarship that has raised significant questions about how accurately one can construct the 'world behind the text' of the biblical narrative or the world of the lands of the Bible, at least from the Bible itself. They will also be aware of the blurring of lines between biblical characters as historical actors, as representations of historical figures or as narrative

16.Tomasi, L., 2002, 'Homo Viator: From Pilgrimage to Religious Tourism via the Journey', in W.H. Swatos \& L. Tomasi (eds.), From Medieval Pilgrimage to Religious Tourism, p. 21, Praeger, Westport.

17.Tomasi, 'Homo Viator', p. 20

18.Tomasi, 'Homo Viator', p. 20

19.Eade and Sallnow, 'Introduction', p. 5.

20.Davies, Pilgrimage Yesterday and Today, p. 206

21.Egeria's Travels 5.8, as quoted earlier. characters with little or no connection to history. ${ }^{22}$ There may, therefore, be competing discourses within the student/ pilgrim/tourist herself as she seeks an encounter with the sacred in places that centuries of pilgrimage have named holy but which scholarly analysis may separate from the text in a way that would have been completely unfamiliar to Egeria and many later pilgrims across the Christian centuries. There will be multiple meanings and understandings as history and archaeology are layered with text and religious experience to constitute the study tour. The discourses are also becoming more complex as women once again enter the worlds of both pilgrimage and pilgrimage studies and the category of gender is brought to bear on the fields of analysis. ${ }^{23}$

\section{With women of the biblical lands}

In turning now to a consideration of women pilgrims or scholars and their engagement with the women of the biblical narrative, I am participating with Luce Irigaray in the recognition that 'there is a genealogy of women' (Irigaray 1993:19). She goes on to offer an invitation that could be said to characterise what follows in this essay:

Let us try to situate ourselves within that female genealogy so that we can win and hold on to our identity. Let us not forget, moreover, that we already have a history, that certain women, despite all the cultural obstacles, have made their mark upon history and all too often have been forgotten by us. ${ }^{24}$

(Irigaray 1993:19)

As indicated earlier, this article will not allow me the space to explore the relationship between biblical women as historical or narrative characters but whatever the blurring of these lines, it is undeniable that there were women who participated in the shaping of the histories and cultures that are the contexts from which the Bible emerged and that their voices can be heard in the text and the shaping of the text, however faintly. ${ }^{25}$ There is therefore, a genealogy of biblical

22. This discussion will cross the wide range of historical and narrative critical works that characterise the past three decades of biblical scholarship, especially as historical and narrative critical methods clashed in the 1980s and 1990s. In relation to the study of biblical women, Monika Fander's 'Historical-Critical Methods', in Searching the Scriptures-Volume One: A Feminist Introduction, ed. Elizabeth Schüssler Fiorenza (1993), pp. 205-224, explores the way in which the history of biblical women might be reconstructed. Elizabeth Struthers Malbon and Janice Capel Anderson, 'Literary-Critical Methods' in Searching the Scriptures-Volume One: A Feminist Introduction, pp. 241-254, shows how the literary critical perspective, focused on the characters of the narrative and the world view of the reader, can allow for multi-dimensional ways of reading the women of the biblical text, not over against the historical but together with it, especially when approached from a feminist critical perspective.

23.Julia Bolton Holloway, 'Helena, Egeria, and Paula: The Bible and Women Pilgrims', $\mathrm{http}: / /$ meltingpot.fortunecity.com/ukraine/324/egeria.html (1997) and idem ' 'Helena, Egeria, Paula, Eustochium, Pega, Bridget, Guthrithyr, Margaret, Isolda, 'Birgitta, Catheritisti/ www.umilta.net/egeria.hthl (2000) retrieves some of the early Christian women who made pilgrimage to the lands of the Bible, a topic which I cannot treat in more detail here. Martha Ann Kirk, Women of Bible Lands: A Pilgrimage to Compassion and Wisdom (2004), is foundational for making pilgrimage with women to the lands of the Bible. Literature is also emerging in relation to pilgrimage to Goddess sites. See Jean Shinoda Bolen, Crossing to Avalon: A Woman's Midlife Pilgrimage (1994), Carol P. Christ, Odyssey with the Goddess: A Spiritual Quest in Crete (1995) and Kathryn Rountree, 'Goddess Pilgrims as Tourists: Inscribing the Body through Sacred Travel', Sociology of Religion 63(4) (2002), 475-96. Not all of this literature will be able to be engaged with in what follows. I wish, however, to acknowledge the extensive feminist and gender studies of biblical narratives, of images of the divine and of pilgrimage that have become available in recent decades.

24.Irigaray, L., 1993, Sexes and Genealogies, transl. Gillian C. Gill, Columbia University Press, New York.

25.There has been a wealth of scholarship that has addressed this over the past three decades, a small portion of which will be cited below. 
women and of those who have gone on pilgrimage to explore, in various ways, their 'mark upon history'. ${ }^{26}$

\section{Beginning in Jerusalem}

In seeking a way to organise the details of a pilgrimage with women of the biblical lands, a geographic approach seemed most appropriate, beginning with Jerusalem and moving out in ever widening circles. Starting our pilgrimage in Jerusalem would turn attention to Golgotha, the place of the death and resurrection of Jesus for it is here that the stories of the women disciples of Jesus, whom the gospel records as faithful to the foot of the cross and beyond, are located (Mk 15:40-41, 47, 16:1-8; Mt 27:55-56, 61, 28:1-10; Lk 23:49; 24:1-11; Jn 19:25$27,20: 1-3,11-18) .{ }^{27}$ Standing at the rock of Golgotha, which would have been outside the 1st century walls of Jerusalem, ${ }^{28}$ the student or pilgrim can stand with many women who are said to have come up with Jesus or followed him from Galilee and who may, therefore, have been disciples..$^{29}$ Many of these women are named, which enables a more explicit remembering and celebrating of them; they include:

- Mary Magdalene (Mk 15:40; Mt 27:56; Jn 19:25)

- another Mary, mother of James and Joses or Joseph (Mk 15:40; Mt 27:56)

- Salome (Mk 15:40)

- the mother of the sons of Zebedee (Mt 27:56)

- Mary, the mother of Jesus and her sister, the wife of Clophas (Jn 19:25).

The consistency of the tradition across the four gospels in placing women disciples at the cross as witnesses of Jesus' final hours as well as its challenge to gendered expectations in relation to the space or place of women and men, given that this was a public place of Roman crucifixion, strengthens the claim of these women on the Christian imagination and will raise questions of historicity. ${ }^{30}$ The scholar or pilgrim will grapple with such questions by drawing on the variety of approaches currently being used in biblical scholarship

26.I have already pointed to the significance of Egeria and the account of her travels that we have by virtue of Valerius. We learn of the journeys of other women pilgrims often through the writings of men and hence through a male lens: Helena for whom Eusebius in his Vita Constantini is the primary source (for an accoun of the history and legend of Helena, see Hunt, Holy Land Pilgrimage, pp. 28-49 and more cursorily, Kirk, Women of Bible Lands, pp. 43-49); Melania the Elde and Paula whose pilgrimages Palladius and Jerome describe (Kirk, Women of Bible Lands, p. 27 and Hunt, Holy Land Pilgrimage, pp. 76-82, 168-174) and Poeminia whose extravagant pilgrimage comes to light in the Coptic Life of John of Lycopolis and in the Life of Peter the Iberian (Hunt, Holy Land Pilgrimage, pp. 76-80, 160161). We may indeed hear the voice of Paula and Eustocium, her daughter, in The Letter of Paula and Eustochium to Marcella about the Holy Places, a letter included amongst Jerome's letters but the purported authorship by Jerome is questioned by Holloway, 'Helena, Egeria, and Paula', 6-7.

27.Carolyn Osiek, 'The Women at the Tomb: What Are They Doing There?' Ex Auditu 9 (1993), 97-107; and Kathleen E. Corley, Women and the Historical Jesus: Feminist Myths of Christian Origins (2002), pp. 107-139.

28.Jerome Murphy-O'Connor, The Holy Land: An Oxford Archaeological Guide from Earliest Times to 1700 , 4th rev. \& expanded ed. (1998), p. 45. This guide is from Earliest Times to 1700, 4th rev. \& expanded ed. (1998), p. 45. This guide is hence could be consulted for further data in relation to each site in Israel discussed below.

29 This is a contested issue in biblical scholarship. Significant work by feminist biblical scholars has, I believe, demonstrated that there were women amongst the discipleship group around Jesus. For an insight into this discussion, see Elaine Mary Wainwright, Towards a Feminist Critical Reading of the Gospel according to Matthew, Beihefte zur Zeitschrift für die neutestamentlich Wissenschaft 60 (1991), Matthew, Beihefte zur Zeitschrift für die neutestamentlich Wissenschaft 60 (1991),
pp. 288-318; and Susan Miller, Women in Mark's Gospel (2004), Journal for the pp. 288-318; and Susan Miller, Women in Mark's Gospel (2004), Jour
Study of the New Testament: Supplement Series 259, pp. 153-204.

30.In particular see Corley, Women and the Historical Jesus, pp. 107-139. providing her with a particular discourse or fields of discourse to articulate the experience of encountering women at this site, a tradition-rich and spirituality-rich location within Christianity.

The scholars or pilgrims can celebrate and engage personally with the discipleship of women par excellence here. She may associate with the gospel women's fidelity within the community of discipleship, their fidelity to Jesus as teacher, healer and friend within a shared community of those become teachers, healers and friends as disciples. ${ }^{31}$ But to remain with the women, torn with grief and with the crucified Jesus wracked in excruciating pain, is to recall the many ways in which both women and men have been crucified down through history into our own day. The image of the crucified one, therefore, that women pilgrims evoke as they stand with the women disciples at Golgotha, may be that of the crucified woman who has been depicted in different ways both historically and in recent times. ${ }^{32}$ The body of the crucified one is configured with the sufferings of the women and men of history.

This experience of Golgotha may send women on pilgrimage out of Jerusalem to another site of inhuman killing and butchering, worse, perhaps than the Romans' cruel tool. We are impelled just north of the city to Gibeah where an unnamed woman who is identified as a Levite's concubine is ravaged all night by the men of Gibeah, left more dead than alive on the doorstep of the house where she was lodging with her husband, and then cut up into twelve pieces by him whose honour had been tarnished (see Jdg 19). Mieke Bal provides the most cogent interpretation of this text, identifying the woman not as the commonly understood concubine but rather from a patrilocal tradition of marriage in which the woman generally stayed in the house of her father. In this story, she is caught between the house of her father and the house of her virilocal husband. The struggles associated with a socio-cultural shift in marriage structures are played out on the body of the woman of Bethlehem just as wars and other socio-political and economic conflicts have been written onto the bodies of countless women throughout the ages. ${ }^{33}$ To pause on pilgrimage with the woman brutalised at Gibeah is to remember all such women and it is to weep with the Womb Compassionate God, the God of rahamim whose gracious and faithful compassion encompasses all who suffer. ${ }^{34}$ It is, however, a confrontation of one's spirit to visit this site. The brutality of this story and

31.Mary-Rose D'Angelo, 'Re-membering Jesus: Women, Prophecy and Resistance in the Memory of the Early Churches', Horizons 19 (1992), 199-218, imagines the discipleship community as one of prophets and teachers. In Women Healing/ Healing Women: The Genderization of Healing in Early Christianity (2006), p.100, Elaine Wainwright suggests that this should be extended to re-membering the community as one of healers as well as prophets and teachers.

32.Ilse E. Friesen, The Female Crucifix: Images of St. Wilgefortis since the Middle Ages (2001). Arthur Boyd's 'Crucifixion, Shoalhaven' was included in the exhibition Beyond Belief: Modern Art and the Religious Imagination curated by Rosemary Beyond Belief: Modern Art and the Religious Imagination curated by Rosemary Crumlin (1998) and of it he says, I do not believe it is enough to say he represented all of us. I do not wish to separate the idea of suffering by allowing just the male to
be seen. There has been an awakening consciousness of the potential and force of women in our time' (p. 140).

33.Mieke Bal, Death and Dissymmetry: The Politics of Coherence in the Book of Judges (1988), pp. 95-127.

34.Phyllis Trible, God and the Rhetoric of Sexuality, Overtures to Biblical Theology (1978), pp. 31-59; and Elaine M. Wainwright, 'The Rachamim/Womb Compassion of Israel's God: Shared', http://www.centacarebrisbane.net.au/pastoral_ministries/hospital.php 
the re-member-ing of not only the woman from Bethlehem but all such brutalised women can also evoke a deep-seated sense of anger at such violence which makes one want to cry out 'Never again! Never again!'35 It challenges the scholar or pilgrim to work to change all structures of violence against women, children, men and the environment, indeed against the entire Earth community.

Returning to Jerusalem and the Holy Sepulchre, a visit to the so-called Tomb of Joseph of Arimathea at the back of the basilica reminds the traveller of the many tombs carved from the rock of Jerusalem in the first century whose entrances were then sealed by stones rolled across the entrance. ${ }^{36}$ Here or at the edicule in the centre of the basilica, the pilgrim can encounter the memories, the traces of a number of the same women who witnessed the crucifixion of Jesus (Mk 16:1-8; Mt 28:1-10; Lk 24:1-12; Jn 20:1-18). These are women commissioned to go out on the 'open road to Galilee', ${ }^{37}$ as 'faithful witnesses who do not relinquish their commitment and solidarity with those who fall victim in the struggle against dehumanising powers ${ }^{\prime 38}$ in contrast with the dehumanising powers symbolised biblically in the action of the Levite in Gibeah.

Whilst still in Jerusalem, groups of scholars or pilgrims will not be easily distinguishable from other tourists or religious tourists. They will be using the same buses, visiting similar sites, staying in the same hotels but they will also be found with their site sheets, perhaps staying longer to search out some archaeological complexity or to question guides about historical accuracies. There will be a dimension to their experience that is not there in the multi-dimensionality of the experience of other tourists or pilgrims and for those scholars or pilgrims who seek out the women of the biblical lands, this will constitute yet another dimension, namely that of gender sensitivity and gendered experience as they engage with stories of female biblical characters or female images of the Divine that shape a spirituality grounded in both experience and scholarly engagement. They might remember the many women named and unknown who made pilgrimages to the temple during the history of the city, especially Hannah who bought her pain to her God there (1 Sm 1:3-2:10), symbolic of women who pray in so many different places and in so many different ways. However, they make pilgrimage with women of prayer aware of the ambivalences in the stories of the women remembered, as Lillian Klein indicates. ${ }^{39}$ And at the Broad Wall of Hezekiah, the words of the prophetic woman Huldah could be read as reminder of the many women prophets whose voices were either silenced or excluded from

35.See Phyllis Trible, Texts of Terror: Literary-Feminist Readings of Biblical Narratives, Overtures to Biblical Theology (1984), p. 87.

36.Murphy-O'Connor, The Holy Land, p. 53; and for visual images of such tombs see http://dqhall59.com/tomb.htm (viewed 18 March 2008).

37.This phrase is used by Elisabeth Schüssler Fiorenza, Jesus - Miriam's Child, Sophia's Prophet: Critical Issues in Feminist Christology (1994), pp. 123-128.

38.Schüssler Fiorenza, Jesus, p. 125.

39.Lillian R. Klein, 'Hannah: Marginalized Victim and Social Redeemer', in A Feminist Companion to Samuel and Kings, ed. Athalya Brenner; The Feminist Companion to the Bible 5 (1994), pp. 77-92; and Carol Meyers, 'Hannah and her Sacrifice: Reclaiming Female Agency', in A Feminist Companion to Samuel and Kings, pp. 93-104.
Israel's remembering as well as those few who were included (2 Ki 22:14-20).40

\section{Extending the circle: Bethany, Bethlehem and Beersheba}

The circle widens now beyond Jerusalem to take in Bethany, Ein Karem, Bethlehem, Hebron, Beersheba and the caves of the Judean desert. Bethany is the place where Jesus escaped from Jerusalem, especially during his last days when his life was under threat. It was the place of his friends Mary and Martha whom the Lukan author pits over against one another (Lk 10:38-42). Making pilgrimage with these two gospel women as scholars or pilgrims enables one to claim the diakonia of Martha and the listening in friendship and discipleship of Mary, both of whom may represent women's active engagement in both the teaching and healing ministry in the circles of disciples. ${ }^{41}$ Whilst in Bethany, we remember another woman, the woman of compassion who poured healing ointment on the head of Jesus (Mk 14:3-9; Mt 26:613). She is a healer, healer of Jesus himself at the moment of his most need ${ }^{42}$ and she draws attention to the fact that in the Markan and Matthean narrative, no women appear to be commissioned to heal. ${ }^{43}$ She represents those other women who may well have been at one of the last suppers of Jesus (that at Bethany or that in Jerusalem (Mk 14:17-25; Matthew 26:20-30]). ${ }^{44}$

Ein Karem, the spring of Karem, place of welcome and of visitation, is the site associated with two women bearers of new life (Mary and Elizabeth; Lk 1:39-56) who meet in an embrace that symbolises women's engagement with women in a way that can change the face of the earth - by love and a recognition of new life. ${ }^{45}$ Bethlehem too is a place of life and of birth, Mary's birthing of Jesus (Lk 2:1-7), Ruth's birthing of Obed, both of whom are included in the Matthean genealogy of Jesus in a way which breaks open the neatness and order of the 'male begets male' pattern. ${ }^{46}$ A little further south, the

40.For an imaginative encounter with the voice of Huldah, see Althalya Brenner, I Am ... Biblical Women Tell Their Own Story (2005), pp. 155-162.

41.This is a complex text which has received extensive and differing scholarly attention. See by way of example Barbara Reid, Choosing the Better Part? Women in the Gospel of Luke (1996), pp. 144-162, who summarises many positions. For a creative or imaginative telling of this story, see Wainwright, Women Healing/ Healing Women, pp. 180-182.

42.Elaine M. Wainwright, 'The Pouring out of Healing Ointment: Rereading Mark 14:3-9', in Toward a New Heaven and a New Earth: Essays in Honor of Elisabeth Schüssler Fiorenza, ed. Fernando F. Segovia (2003), pp. 157-178.

43.This is the issue addressed in Wainwright, Women Healing/Healing Women.

44.There are many paintings now which picture the women at the table of those last suppers with the men. See for example Judi Fisher and Janet Wood, eds., A Place at the Table: Women at the Last Supper (1993). For one example of a biblical scholar's discussion of this, see Dorothy A. Lee, 'Presence or Absence: The Question of Women Disciples at the Last Supper'. Pacifica 6 (1993), 1-20; and Tina Beattie's imaginative reconstruction, The Last Supper according to Martha and Mary (2001). It is also significant to note that traditionally artists have painted the anointing woman at the feet of Jesus washing them with her tears or ointment and wiping them with her hair (Mary of Bethany in John 12:1-8 and the unnamed woman of Luke 7:36-50). It is very difficult to find images of the woman healer who pours her ointment over the head of Jesus.

45. Resources such as Miriam Therese Winter's WomanWord might serve those making pilgrimage with women of the biblical narrative: A Feminist Lectionary and Psalter-Women of the New Testament (1990) which supplies lectionary readings, contextualisations and psalms, which could be called on for rituals, celebrated at pilgrimage sites. In relation to the encounter between Mary and Elizabeth, see pp. pilgrimage sites. In relation to the encounter between Mary and Elizabeth, see pp.
2-7. Kirk, Women of Bible Lands, will also be a resource to have in hand during such a pilgrimage as it supplies texts related to and comments on each site. 
pilgrim comes upon Machphelah by Hebron, the field that Abraham bought to bury Sarah (Gn 23:1-20), a place which now commemorates Sarah and Rebekah whilst Rachel's Tomb is located on the edge of Bethlehem. ${ }^{47}$ This tomb, in particular, is a place of pilgrimage for women weeping because they cannot bear children, weeping for the pain of their people. At Beersheba, the well of Abraham reminds those making pilgrimage with the women of the biblical narrative of Sarah and Hagar locked in a struggle structured by patriarchy (Gn 16:1-6). Hagar is driven out into the desert of Beersheba, the place where she names God: El Roi, the God who sees (a woman naming the divine out of her experience). The God of Sarah and Hagar, Rebecca and Rachel can be symbolised in the many figurines of the birthing mother found at many sites of ancient Israel. ${ }^{48}$ Whilst on the edge of the southern desert, the Judean desert and the Murabaat caves, scholars or pilgrims encounter a Jewish woman of the bar Kockba period, namely Babatha, the woman whose documents were found in these caves. Her ingenuity in burying her documents in a cave at the time of revolution allows the scholar or pilgrim a glimpse into the lives of Jewish women of the early 2nd century, their access to land, to vineyards and their engagement in legal and commercial activity. ${ }^{49}$ Her archive is regularly on display in the Shrine of the Book museum in Jerusalem.

\section{Extending again: Egypt and Galilee}

The next widening of our circle could take in Egypt to the south and Galilee to the north, both rich in resources for making pilgrimage with the women of the biblical lands and their imagining of the Divine. Out of necessity, my examples will be very selective. In Egypt, I have chosen to remember my own experience of a first visit to the Island of Philae with its temple of Isis. As I made my way through the temple, I was overwhelmed by image after image of the divine depicted female as healer and restorer of life. At a subsequent Sound and Light Show at the temple, the presence of this Female Divine was palpable..$^{50}$ It is likely that it was from the Egyptian hymns to Isis that Israel drew language and images to praise Sophia or Wisdom as in Wisdom 7:22-30.51 She dances through the imagination of scholars or pilgrims calling them forth as women and men of a new imagination..$^{52}$

Some of the women of Galilee have already been encountered in Jerusalem but the scholar or pilgrim's journey takes her

47.For a consideration of these women's stories, see Alice Ogden Bellis, Helpmates, Harlots, Heroes: Women's Stories in the Hebrew Bible (1994), pp. 67-98, with her extensive bibliography.

48.For an extensive study of these images amongst others, see Othmar Keel and Christoph Uehlinger, Gods, Goddesses, and Images of God in Ancient Israel, translated by Thomas H. Trapp (1998), pp. 72-75 (Plate 82), 198-204, 323-349. For a more recent study see William G. Dever, Did God Have a Wife? Archaeology and Folk Religion in Ancient Israel (2005), pp. 176-251.

49.For translations of the documents, see Naphtali Lewis, ed. The Documents from the Bar Kokhba Period in the Cave of Letters (1989).

50.For a classic study of Isis, see R.E. Witt, Isis in the Ancient World (1971).

51.Silvia Schroer, Wisdom Has Built Her House: Studies on the Figure of Sophia in the Bible, translated by Linda M. Maloney and William McDonough (2000), pp. 104110, and throughout for a study of Wisdom in Israel.

52.For such a perspective, see Susan Cady, Marian Ronan and Hal Taussig, Sophia: The Future of Feminist Spirituality (1986). now to their homeland. At Capernaum, in the house of Peter, Peter's mother-in-law is healed (Mt 8:14-15; Mk 1:29-31; Lk 4:38-39). A modern church now covers the ancient 1st century house that was itself surrounded by a Byzantine octagonal church. ${ }^{53}$ In Matthew's gospel, the woman's healing is told as a combined call or healing story so that she can be imagined as one of the women at the foot of the cross or as an early missionary woman telling the Jesus story as it was taken north into Syria..$^{54}$ At the Capernaum site, a mosaic floor was found depicting the port of Migdal just south of Capernaum. This fishing town is the place by which Mary who is said to be of Magdala was named. She is presented in the gospel narrative as the woman closest to Jesus and is the one whom the Gnostic gospels make the intimate of Jesus, the one to whom Jesus gave knowledge or wisdom..$^{55}$

Moving up into the hill country of Galilee, the scholar or pilgrim may visit Sepphoris, the city that was re-built and fortified in the 1st century CE. The beautiful 'Mona Lisa of the Galilee' mosaic found at this site evokes a world of women in the late Hellenistic and early Roman empires, not only in Galilee but also throughout Asia Minor, Greece and Rome. These women had wealth, undertook professions, moved into the public arena - women who can be encountered through the inscriptions which remember them and through the traces or memories of them found in the Pauline literature. ${ }^{56}$ Making pilgrimage with them and seeking to know as much as possible about these women from the limited data available may be foundational for empowering women today: women have a history, a genealogy of women who took their place in the public arena, who shaped society.

On the hill opposite Sepphoris is Nazareth, the place associated with a woman who has been remembered in ways that have been both life-enhancing and life-denying for women, namely Mary of Nazareth. ${ }^{57}$ Here pilgrims or scholars may recall the story of Mary's visit by the angel (Lk 1:26-38]. Myriads of artists have sought to capture the essence of this story. Kokoschka's depiction seems to take viewers into the very self of the God who took flesh in the womb of a woman - an extraordinary self beyond our comprehending. ${ }^{58}$ It is at sites such as this that the pilgrim or scholar may encounter the sacred through the rich tradition of pilgrimage and spirituality associated with both place and the sacred narrative connected to it.

53.Murphy-O'Connor, The Holy Land, pp. 218-219.

54.Wainwright, Toward a Feminist Critical Reading, pp. 76-87, 177-191.

55.For this latter aspect of Mary of Magdala, see Karen L. King, The Gospel of Mary of Magdala: Jesus and the First Woman Apostle (2003).

56.For the most extensive collection of such resources, see Mary R. Lefkowitz and Maureen B. Fant, eds., Women's Life in Greece and Rome: A Source Book in Translation, 3rd ed. (2005). See also Eric M. Meyers, Ehud Netzer and Caro L. Meyers, Sepphoris (1992), pp. 52-53; and Carol L. Meyers, Eric M. Meyers, Ehud Netzer, and Zeev Weiss, 'The Dionysos Mosaic', in Sepphoris in Galilee: Crosscurrents of Culture, ed., Rebecca Martin Nagy, Carol L. Meyers, Eric, M. Meyers and Zeev Weis (1996), pp. 110-115.

57.See Marina Warner, Alone of All Her Sex: The Myth and Cult of the Virgin Mary (1985); and Elizabeth A. Johnson, Truly our Sister: A Theology of Mary in the Communion of Saints (2003).

58.For a copy of this image see Rosemary Crumlin, Beyond Belief, p. 47 and Diane Apostolos-Cappadona's brief commentary, p. 46, in which she notes that 'an artist in the age of disbelief moves us visually beyond belief toward the eternal mystery of the sacred'. 


\section{Conclusion}

This pilgrimage could be extended into Asia Minor and beyond to Rome. Limiting it to Israel and Egypt has, however, provided a glimpse of what could constitute making pilgrimage with the women of the biblical lands not exclusively as pilgrim, as tourist or as religious tourist but as biblical scholar or feminist biblical scholar who may combine aspects of each category and more. This imagined study tour has taken us to many sites but it has also invited us into a genealogy, a genealogy of women at the heart of the biblical tradition and the early church. It has also evoked multiple images of the Divine, which, when encountered, enable contemporary women to reclaim their heritage anew. Not only women but all pilgrims or students can go on pilgrimage with these women disciples, women leaders who invite the pilgrim into the mystery of God incarnate in Jesus, of Sophia dancing the healing dance that Isis and Hygieia danced.

The sun rises and the sun sets over the sea of Galilee and over the Mediterranean Sea which links the lands travelled, but such a pilgrimage or study tour (even if viewed by others as mere tourism or perhaps as religious tourism) in its multidimensionality and its complexity of discourses amongst its participants, can infuse new light into the darkness of biblical women forgotten, of biblical women silenced, of biblical women obscured and of the female imaging of the divine veiled. To re-member is to provide not only women but the entire Christian community with a new genealogy, a new history.

\section{References}

Bal, M., 1988, Death and dissymmetry: The politics of coherence in the Book of Judges, University of Chicago Press, Chicago.

Beattie, T., 2001, The Last Supper according to Martha and Mary, London, Burns and Oates.

Bellis, A.O., 1994, Helpmates, harlots, heroes: Women's stories in the Hebrew Bible, Westminster/John Knox, Louisville.

Bolen, J.S., 1994, Crossing to Avalon: A woman's midlife pilgrimage HarperSanFrancisco, New York.

Brenner, A., 2005, I am...biblical women tell their own stories, Fortress, Minneapolis.

Cady, S., Ronan, M. \& Taussig, H., 1986, The future of feminist spirituality, Harper \& Row, San Francisco.

Carse, H.R., 2003, 'Creative ambiguities in pilgrimage process', PhD thesis, University of Kent.

Christ, C.P., 1995, Odyssey with the Goddess: A spiritual quest in Crete, Continuum, New York.

Coleman, S. \& Elsner, J., 1995, Pilgrimage past and present: Sacred travel and sacred space in the world religions, British Museum Press, London.

Corley, K., 2002, Women and the historical Jesus: Feminist myths of Christian origins, Polebridge, Santa Rosa.

Crumlin, R. (ed.), 1998, Beyond belief: Modern art and the religious imagination National Gallery of Victoria, Melbourne.

D’Angelo, M.R., 1992, 'Re-membering Jesus: Women, prophecy and resistance in the memory of the early churches,' Horizons 19, 199-218.

Davies, J.G. 1988. Pilgrimage yesterday and today: Why? Where? How? SCM, London.

Dever, W.G., 2005, Did God have a wife? Archaeology and folk religion in ancien Israel, Eerdmans, Grand Rapids.

Eade, J. \& Sallnow, M.J., 1991, 'Introduction,' in J. Eade \& M.J. Sallnow (eds.) Contesting the sacred: The anthropology of Christian pilgrimage, pp. 1-29, Routledge, New York.

Fander, M., 1993, 'Historical-critical methods,' in E. Schüssler Fiorenza (ed.), Searching the scriptures-volume one: a feminist introduction, pp. 205-224, Crossroad, New York.

Fisher, J. \& Wood, J., 1993, A place at the table: Women at the Last Supper, The Joint Board of Christian Education, Melbourne.

Friesen, I.E., 2001, The female crucifix: Images of St. Wilgefortis since the Middle Ages, Wilfrid Laurier University Press, Waterloo.
Holloway, J.B 1997, Helena, Egeria, and Paula: The Bible and women pilgrims, viewed 19 March 2008, from http://meltingpot.fortunecity.com/ukraine/324/egeria.html

Holloway, J.B., 2000. Helena, Egeria, Paula, Eustochium, Pega, Bridget, Guthrithyr, Margaret, Isolda, Birgitta, Catherine, Margery, Rose and Julia: The Bible and women pilgrims, viewed 19 March 2008, from http://www.umilta.net/egeria.htm

Hunt, E.D., 1982, Holy Land pilgrimage in the later Roman Empire AD 312-460, Clarendon Press Oxford.

Irigaray, L., 1993, Sexes and genealogies, Columbia University Press, New York.

Johnson, E.A., 2003, Truly our sister: A theology of Mary in the communion of saints, Continuum, New York.

Keel, O. \& Uehlinger, C., 1998, Gods, goddesses, and images of God in Ancient Israel, Fortress, Minneapolis.

King, K.L., 2003, The gospel of Mary of Magdala: Jesus and the first woman apostle, Polebridge, Santa Rosa.

Kirk, M.A., 2004, Women of Bible lands: A pilgrimage to compassion and wisdom, Liturgical Press, Collegeville.

Klein, L.R., 1994, 'Hannah: Marginalized victim and social redeemer,' in A. Brenner (ed.), A feminist companion to Samuel and Kings, pp. 77-92, Sheffield Academic Press, Sheffield.

Lee, D.A., 1993, 'Presence or absence: the question of women disciples at the Last Supper,' Pacifica 6, 1-20.

Lefkowitz, M.R. \& M.B. Fant, (eds.), 2005, Women's life in Greece and Rome: A source book in translation, 3rd edn, Johns Hopkins University Press, Baltimore.

Lewis, N. (ed.), 1989, The documents from the Bar Kokhba period in the Cave of Letters, Israel Exploration Society, Jerusalem.

Malbon, E.S. \& Anderson, J.C., 1993, 'Literary-Critical methods,' in E. Schüssler Fiorenza (ed.), Searching the scriptures-volume one: a feminist introduction, pp. 241-254, Crossroad, New York.

Meyers, C.L., Meyers, E.M., Netzer, E. \& Weiss, Z., 1996, 'The Dionysos Mosaic, in R.M. Nagy, C.L. Meyers, E.M. Meyers \& Z. Weiss (eds.), Sepphoris in Galilee: Cross currents of culture, pp. 110-115, North Carolina Museum of Art, Raleigh.

Meyers, C., 1994, 'Hannah and her sacrifice: reclaiming female agency,' in A. Brenner (ed.), A feminist companion to Samuel and Kings, pp. 93-104, Sheffield Academic Press, Sheffield.

Meyers, E M., Netzer, E. \& Meyers, C.L., 1992, Sepphoris, Eisenbrauns, Winona Lake.

Miller, S., 2004, Women in Mark's Gospel, T \& T Clark International, London.

Murphy-O'Connor, J., 1998, The Holy Land: An Oxford archaeological guide from earliest times to 1700, 4th rev. \& exp. edn., Oxford University Press, Oxford.

Osiek, C., 1993, 'The Women at the Tomb: What Are They Doing There?' Ex Auditu 9, 97-107.

Prior, M., 1994, 'Pilgrimage to the Holy Land, yesterday and today' in M. Prior \& W. Taylor (eds.), Christians in the Holy Land, pp. 169-199, World of Islam Festival Trust, London.

Reid, B.E., 1996, Choosing the better part? Women in the Gospel of Luke, Liturgical Press Collegeville.

Rountree, K., 2002, 'Goddess pilgrims as tourists: Inscribing the body through sacred travel', Sociology of Religion 63(4), 475-496. doi: 10.2307/3712303

Schroer, S., 2000, Wisdom has built her house: Studies on the figure of Sophia in the Bible, Liturgical press, Collegeville.

Schüssler Fiorenza, E., 1984, Bread not stone: The challenge of feminist biblical interpretation, Beacon, Boston.

Schüssler Fiorenza, E., 1994, Jesus - Miriam's child, Sophia's prophet: critical issues in feminist Christology, Continuum, New York.

Schüssler Fiorenza, E., 2001, Wisdom ways: Introducing feminist biblical interpretation, Orbis, Maryknoll.

Swatos, W.H. \& Tomasi, L., (eds.), 2002, From medieval pilgrimage to religious tourism The social and cultural economics of piety, Praeger, Westport.

Tomasi, L., 2002, 'Homo Viator: from pilgrimage to religious tourism via the journey,' in W.H. Swatos \& L. Tomasi (eds.), From medieval pilgrimage to religious tourism: The social and cultural economics of piety, pp. 1-24, Praeger, Westport.

Trible, P., 1978, God and the rhetoric of sexuality, Fortress, Minneapolis

Trible, P., 1984, Texts of terror, Fortress, Philadelphia.

Wainwright, E.M., n.d., 'The Rachamim/Womb Compassion of Israel's God: Shared', viewed, n.d., http://www.centacarebrisbane.net.au/pastoral_ministries/hospital. php.

Wainwright, E.M., 1991, Towards a feminist critical reading of the Gospel according to Matthew, BZNW 60, de Gruyter, Berlin.

Wainwright, E.M., 2003, 'The pouring out of healing ointment: Rereading Mark 14:39,' in F.F. Segovia (ed.), Toward a new heaven and a new earth: Essays in honor of Elisabeth Schüssler Fiorenza, pp. 157-178, Orbis, Maryknoll.

Wainwright, E.M., 2006, Women healing/healing women: Genderization of healing in early Christianity, Equinox, London.

Warner, M., 1985, Alone of all her sex: The myth and cult of the Virgin Mary, Pan Books, London.

Wilkinson, J., 1981, Egeria's travels to the Holy Land, rev. edn., Ariel Publishing House, Jerusalem.

Winter, M.T., 1990, WomanWord: A feminist lectionary and psalter-women of the New Testament, Collins Dove, North Blackburn.

Witt, R.E., 1971, Isis in the ancient world, Johns Hopkins University Press, Baltimore. 